\title{
Interactions in the Agrobacterium-soybean system and capability of some Brazilian soybean cultivars to produce somatic embryos
}

\author{
Antonio Orlando Di Mauro ${ }^{1}$, José Carlos Martins de Nóbregal, Sonia Marli \\ Z. Di Mauro' ${ }^{l}$ and Glenn Burton Collins ${ }^{2}$
}

\begin{abstract}
Twenty-five Brazilian soybean cultivars were studied for susceptibility to four strains of Agrobacterium tumefaciens (C58, Ach5, Bo542 and A281) and for their ability to produce somatic embryos. Twelve plants of each cultivar were inoculated in a greenhouse at 46 weeks of age, using 12 inoculation sites per plant. The number of galls formed on plants were counted 8-10 weeks after inoculation. To study ability to produce somatic embryos, immature cotyledons, 4-6 mm in length, were plated onto N10 medium for induction of somatic embryogenesis, using four Petri dishes with 20 cotyledons for each cultivar. The embryogenic tissues were transferred onto new N10 medium six times at 15-day intervals and the number of somatic embryos per cultivar determined. Significant interaction between soybean cultivars and A. tumefaciens strains was observed; the most virulent strain was A281. The opine type apparently had no effect on strain virulence, and the most embryogenic cultivars were IAS-5, Cristalina, FT-Cometa, IAC-7 and OC-3.
\end{abstract}

\section{INTRODUCTION}

Soybean (Glycine max L. Merrill) cultivars differ in susceptibility to Agrobacterium tumefaciens strains (Byrne et al., 1987; Delzer et al., 1990; Bailey et al., 1994; Mauro et al., 1995). Although no relationship exists between a given soybean cultivar susceptibility and its somatic embryo susceptibility to A. tumefaciens, information about cultivar susceptibility to A. tumefaciens strains may be useful in studies related to specificity between soybean cultivars and $A$. tumefaciens strains.

Several studies have shown differences among soybean cultivars in vitro regeneration via somatic embryogenesis (Owens and Cress, 1985; Komatsuda and Okyama, 1988; Delzer et al., 1990; Mauro et al., 1995). Previous studies developed by Bodanese-Zanettini et al. (1993) and Mauro et al. (1994a) found cultivar IAS-5 among the most embryogenic. Successful Agrobacterium-mediated transformation of the soybean depends on embryogenic capability, since somatic embryos can easily be infected and transformed by strains of $A$. tumefaciens. Few Brazilian soybean cultivars have been studied so far for their interactions with strains of $A$. tumefaciens or for their ability to produce somatic embryos. The objectives of this research were to study strain and cultivar specificity in the Agrobacterium-soybean system and to identify some Brazilian soybean cultivars with good ability to produce somatic embryos.

\section{MATERIAL AND METHODS}

\section{Plant material and bacterial strains}

The soybean cultivars used in this study were: IAC-1, IAC-4, IAC-6, IAC-7, IAC-17, FT-Cometa, Cristalina, Savana, Viçoja, Peking, Paraná, IAS-5, Bossier, IAC PL-1, IAC-100, CAC-1, OC-4, OC-14, OC-3, JAB-11, UFV-15, UFV-14, UFV-10, UFV-1, UFV-9 and UFV-5. The cultivar Peking was used as susceptible (Delzer et al., 1990).

The wild-type strains of A. tumefaciens C58 (nopaline), Ach5 (octopine), Bo542 (agropine) and A281 (agropine) were used for inducing gall formation on plants, since according to Petit et al. (1983), different opines could be responsible for pathogenicity observed in tumor formation. The experimental plots consisted of pots containing four plants of each genotype; three replications were used in a randomized block experimental design. The Agrobacterium cultures were initiated on LB solid medium. To prepare the inoculum a small amount of each bacterial colony was taken from the solid medium with a sterile loop and transferred to 250-ml flasks containing $25 \mathrm{ml}$ of LB liquid medium (Sambrook et al., 1989).

To reach log phase growth (OD value ranging from 0.7 to 0.8 at $600 \mathrm{~nm}$ ) the flasks were incubated overnight at $28^{\circ} \mathrm{C}$ in a rotary shaker at $180 \mathrm{rpm}$. After incubation, the content of each flask was poured into sterile centrifuge tubes and centrifuged at 10,000 rpm $(12,062 \mathrm{~g})$ for

${ }^{l}$ Departamento de Fitotecnia, Faculdade de Ciências Agrárias e Veterinárias, UNESP, Campus de Jaboticabal, 14870-000 Jaboticabal, SP, Brasil. Send correspondence to A.O.M. E-mail: orlando@fcav.unesp.br. ${ }^{2}$ Department of Agronomy, University of Kentucky, Lexington, KY 40546-0091, USA. 
$10 \mathrm{~min}$ at $4^{\circ} \mathrm{C}$. The supernatant was discarded, $15 \mathrm{ml}$ of MSO liquid medium (Murashige and Skoog, 1962) added and the pellet resuspended.

\section{Somatic embryogenesis induction}

Plants of each cultivar were cultivated in the field and when immature cotyledons were 4 to $6 \mathrm{~mm}$ long 40 pods of each cultivar were collected. Pods were washed thoroughly but gently in a $1 \%$ neutral detergent solution, rinsed in deionized water, placed in $70 \%$ isopropanol solution for $30 \mathrm{~s}$, and drained. They were then placed in $20 \%$ $\mathrm{NaOCl}$ for 15 min and rinsed three times with sterile water (Lazzeri et al. 1985). After asepsis, the cotyledons were excised and plated on solid N10 medium (medium MS of Murashige and Skoog, 1962, supplemented with 10 $\mathrm{mg} / \mathrm{l}$ of NAA) solidified with Phytagel $(0.2 \%)$. Four Petri dishes $(60 \times 15 \mathrm{~mm})$, each containing 20 immature cotyledons, were used per cultivar and considered as replications in a randomized block experimental design.

Embryogenic tissue was transferred to fresh N10 medium at 15-day intervals for 90 days, and kept in a growth chamber at $26^{\circ} \mathrm{C}$ with a 23/1-hour light/dark photoperiod. Petri dishes containing embryogenic tissue of each cultivar were examined every 15 days for the presence of somatic embryos and the somatic embryo number per cultivar per replication was counted.

\section{Plant inoculations and statistical analysis}

Inoculations were performed when plants reached $\mathrm{V}_{8}$ growth stage (Fehr and Caviness, 1980) using a hypodermal syringe $(5 \mathrm{ml})$. Slight pressure was used to form a drop of bacterial suspension at the tip of the needle, which was used to make a cut across the epidermis and cortex. Four sites per internode, in the three first internodes, approximately $1 \mathrm{~cm}$ apart were inoculated, resulting in 12 wound sites per plant. Four to six weeks after inoculation, the plants were scored by counting the number of galls larger than $0.5 \mathrm{~cm}$ in diameter, per genotype, per replication, per strain of A. tumefaciens. The suggestions of Mauro et al. (1994b) were always followed, since the authors found better Agrobacterium tumefaciens infection results by performing the inoculations $5 \mathrm{~h}$ after inoculum preparation.

The number of galls derived from inoculations as well as the number of somatic embryos were transformed to ( $\mathrm{x}$ $+0.5)^{1 / 2}$ and submitted to variance analysis according to procedures suggested by Snedecor and Cochran (1989). Comparisons among means were performed through the Scott-Knott and Tukey tests, at 5\% probability level.

\section{RESULTS AND DISCUSSION}

The variance analysis results for the number of galls derived from inoculation (Table I) showed differences in
Table I - Analysis of variance for the number of galls resulting from inoculation of soybean cultivars with four strains of A. tumefaciens $(\mathrm{CV} \%=17.15 ;$ Mean $=1.7127)$.

\begin{tabular}{|lrrrc|}
\hline Source of variation & d.f. & \multicolumn{1}{c}{ SS } & MS & F-test \\
\hline Rep./Strains & 52 & 8.3674 & 0.1609 & - \\
Cultivars (Cult.) & 25 & 207.3779 & 8.2951 & $96.1820^{*}$ \\
Strains (Str.) & 3 & 15.9182 & 5.3061 & $61.1820^{*}$ \\
Cult. x Str. & 75 & 116.7861 & 1.5571 & $18.0550^{*}$ \\
& & & & \\
Cult./Str.1 & 25 & 75.8933 & 3.0357 & $35.2161^{*}$ \\
Cult./Str.2 & 25 & 70.4060 & 2.8162 & $32.6705^{*}$ \\
Cult./Str.3 & 25 & 71.1045 & 2.8442 & $32.9954^{*}$ \\
Cult./Str.4 & 25 & 106.7602 & 4.2704 & $49.5406^{*}$ \\
& & & & \\
Error & 156 & 13.4541 & 0.0862 & - \\
\hline
\end{tabular}

"Significant at the $1 \%$ level of probability. d.f. = Degrees of freedom; SS = sum of squares; MS = mean square.

soybean cultivar susceptibility and in pathogenicity degree of A. tumefaciens strain in the soybean cultivars. Interaction between soybean cultivars and A. tumefaciens strain was also observed. Similar interactions were previously reported by Byrne et al. (1987), suggesting possible specificity between strains and cultivars. The $17.15 \%$ variation indicates reliable results.

The mean number of galls derived from inoculations with each strain of A. tumefaciens on the soybean cultivars (Table II) showed IAS-5 susceptibility to strain A281, FT-Cometa to strain Ach5, and IAC-7 to strain Bo542. IAC PL-1 was susceptible to strains C58 and A281, IAC-4 susceptible to strains Ach5 and Bo542 but resistant to strain C58, and IAC-100 susceptible to strain Ach5 only. Cultivars OC-14, IAC-17, OC-4, Paraná and UFV-14 were resistant to all strains of $A$. tumefaciens; Peking, as expected, was highly susceptible to all four strains.

Table II also shows that strain A281 was the most virulent, followed by strains Bo542, Ach5 and C58, with no significant differences among them. Bailey et al. (1994) and Mauro et al. (1995) also reported for strain A281 high virulence to the soybean cultivars tested. The results also suggested that additional factors apart from opine type may contribute to pathogenicity degree of the Agrobacterium strains since significant differences were observed between strains carrying the same opine (A281 and Bo542).

Table III summarizes the results of numerical analysis of somatic embryos produced by each cultivar. The Ftest showed differences in somatic embryogenesis capability among cultivars; comparisons among means for the number of somatic embryos produced by each soybean cultivar confirmed these differences. Cultivars IAS-5, Cristalina, FT-Cometa, IAC-7 and OC-3 produced the highest numbers of somatic embryos and could therefore be indicated as embryogenic parentals for studies related to the genetics of embryogenic capability in the soybean. Cul- 
Table II - Mean number of galls $(x+0.5)^{1 / 2}$ in each soybean cultivar produced by Agrobacterium tumefaciens strains.

\begin{tabular}{|c|c|c|c|c|c|}
\hline \multirow{2}{*}{$\begin{array}{l}\text { Soybean } \\
\text { cultivars }\end{array}$} & \multicolumn{4}{|c|}{ A. tumefaciens strains } & \multirow[t]{2}{*}{ Mean $^{1}$} \\
\hline & C58 & Ach5 & Bo542 & A281 & \\
\hline IAC-1 & $2.10 \mathrm{C}$ & $2.26 \mathrm{~A}$ & $2.84 \mathrm{~B}$ & $2.91 \mathrm{D}$ & $2.53 \mathrm{~A}$ \\
\hline IAC-4 & $0.88 \mathrm{D}$ & $3.18 \mathrm{~A}$ & $3.28 \mathrm{~A}$ & $3.76 \mathrm{~B}$ & $2.78 \mathrm{~A}$ \\
\hline IAC-6 & $1.00 \mathrm{D}$ & $2.20 \mathrm{~A}$ & $2.11 \mathrm{C}$ & $2.26 \mathrm{E}$ & $1.89 \mathrm{~B}$ \\
\hline IAC-7 & $0.71 \mathrm{D}$ & $2.47 \mathrm{~A}$ & $3.65 \mathrm{~A}$ & $2.41 \mathrm{D}$ & $2.31 \mathrm{~B}$ \\
\hline IAC-17 & $0.71 \mathrm{D}$ & $0.71 \mathrm{~B}$ & $0.71 \mathrm{E}$ & $0.71 \mathrm{~F}$ & $0.71 \mathrm{C}$ \\
\hline FT-Cometa & $1.86 \mathrm{C}$ & $2.26 \mathrm{~A}$ & $1.00 \mathrm{D}$ & $1.00 \mathrm{~F}$ & $1.53 \mathrm{C}$ \\
\hline Cristalina & $2.26 \mathrm{C}$ & $0.71 \mathrm{~B}$ & $1.93 \mathrm{C}$ & 2.67D & 1.89B \\
\hline Savana & $0.71 \mathrm{D}$ & $2.74 \mathrm{~A}$ & 1.10D & $0.71 \mathrm{~F}$ & $1.31 \mathrm{C}$ \\
\hline Viçoja & $0.71 \mathrm{D}$ & 1.74B & $0.71 \mathrm{E}$ & $1.95 \mathrm{E}$ & $1.28 \mathrm{C}$ \\
\hline Peking (C) & $3.83 \mathrm{~A}$ & $3.89 \mathrm{~A}$ & $3.29 \mathrm{~A}$ & $4.38 \mathrm{~A}$ & $3.84 \mathrm{~A}$ \\
\hline Paraná & $0.71 \mathrm{D}$ & $0.71 \mathrm{~B}$ & $0.71 \mathrm{E}$ & $1.00 \mathrm{~F}$ & $0.78 \mathrm{C}$ \\
\hline IAS-5 & $0.71 \mathrm{D}$ & $0.71 \mathrm{~B}$ & $0.71 \mathrm{E}$ & $3.77 \mathrm{~B}$ & $1.48 \mathrm{C}$ \\
\hline Bossier & $0.71 \mathrm{D}$ & $0.71 \mathrm{~B}$ & $0.71 \mathrm{E}$ & $2.03 \mathrm{E}$ & $1.04 \mathrm{C}$ \\
\hline IAC PL-1 & $3.87 \mathrm{~A}$ & $1.39 \mathrm{~B}$ & $2.73 \mathrm{~B}$ & $3.90 \mathrm{~B}$ & $2.97 \mathrm{~A}$ \\
\hline IAC-100 & $0.71 \mathrm{D}$ & $3.31 \mathrm{~A}$ & $1.18 \mathrm{D}$ & $0.71 \mathrm{~F}$ & $0.83 \mathrm{C}$ \\
\hline CAC-1 & $1.00 \mathrm{D}$ & $0.71 \mathrm{~B}$ & $1.86 \mathrm{C}$ & $2.59 \mathrm{D}$ & $2.19 \mathrm{~B}$ \\
\hline OC-4 & $1.11 \mathrm{D}$ & 1.17B & $0.71 \mathrm{E}$ & $0.71 \mathrm{~F}$ & $0.93 \mathrm{C}$ \\
\hline OC-14 & $0.71 \mathrm{D}$ & $0.71 \mathrm{~B}$ & $0.71 \mathrm{E}$ & $0.71 \mathrm{~F}$ & $0.78 \mathrm{C}$ \\
\hline OC-3 & $1.93 \mathrm{C}$ & $0.71 \mathrm{~B}$ & $1.00 \mathrm{D}$ & $0.71 \mathrm{~F}$ & $1.09 \mathrm{C}$ \\
\hline JAB-11 & $2.53 \mathrm{C}$ & $0.71 \mathrm{~B}$ & $2.46 \mathrm{C}$ & 2.67D & $2.09 \mathrm{~B}$ \\
\hline UFV-15 & $1.93 \mathrm{C}$ & $1.43 \mathrm{~B}$ & 1.29D & $2.53 \mathrm{D}$ & $1.80 \mathrm{~B}$ \\
\hline UFV-14 & $0.71 \mathrm{D}$ & $1.00 \mathrm{~B}$ & $0.71 \mathrm{E}$ & $0.71 \mathrm{~F}$ & $0.71 \mathrm{C}$ \\
\hline UFV-10 & $1.81 \mathrm{C}$ & $0.71 \mathrm{~B}$ & $1.65 \mathrm{D}$ & $1.05 \mathrm{~F}$ & $1.31 \mathrm{C}$ \\
\hline UFV-1 & $0.71 \mathrm{D}$ & $1.17 \mathrm{~B}$ & $0.71 \mathrm{E}$ & $2.20 \mathrm{E}$ & $1.20 \mathrm{C}$ \\
\hline UFV-9 & $2.85 \mathrm{~B}$ & $1.67 \mathrm{~B}$ & $2.79 \mathrm{~B}$ & $3.29 \mathrm{C}$ & $2.65 \mathrm{~A}$ \\
\hline UFV-5 & $2.90 \mathrm{~B}$ & $2.48 \mathrm{~A}$ & $1.86 \mathrm{C}$ & $3.22 \mathrm{C}$ & $2.62 \mathrm{~A}$ \\
\hline Mean $^{2}$ & $1.53 \mathrm{~b}$ & $1.59 \mathrm{~b}$ & $1.63 b$ & $2.10 \mathrm{a}$ & \\
\hline
\end{tabular}

${ }^{1}$ Means followed by the same capital letter did not differ by the ScottKnott test at the $5 \%$ level of probability. ${ }^{2}$ Means followed by the same lower case did not differ by the Tukey test at the $5 \%$ level of probability.

tivar IAS-5 produced the highest individual number of somatic embryos, as also reported by Bodanese-Zanettini et al. (1993) and by Mauro et al. (1994a). On the other hand, IAC-1, Savana, Viçoja, Peking, Paraná, Bossier, OC-14, UFV-15, UFV-1, UFV-9 and UFV-5 were non-embryogenic. The variation was $15.78 \%$, indicating reliability.

\section{ACKNOWLEDGMENTS}

Bacterial strains were kindly provided by EMBRAPACENARGEN and the University of Kentucky. Research supported by FAPESP and CNPq. Publication supported by FAPESP.

\section{RESUMO}

Vinte e cinco cultivares brasileiros de soja foram estudados quanto à suscetibilidade a quatro linhagens de Agrobacterium tumefaciens (C58, Ach5, Bo542 e A281) e quanto à capacidade de produzir embriões somáticos. Doze plantas de cada cultivar foram inoculadas, na casa de vegetação, 4-6 semanas após a semeadura, sendo efetuadas 12 inoculações por planta. O número de galhas derivadas dessas inoculações foi contado 8-10 semanas após as inoculações. Para avaliar a capacidade de produção de
Table III - Total (TSE) and mean (MSE) number of somatic embryos ( $\mathrm{x}+$ $0.5)^{1 / 2}$ derived from each soybean cultivar $\left(\mathrm{F}\right.$-test $=25.37^{1} ;$ C.. $\left.. \%=15.78\right)$.

\begin{tabular}{|lrl|}
\hline Soybean cultivar & TSE & MSE $^{2}$ \\
\hline IAC-1 & 0 & $0.71 \mathrm{D}$ \\
IAC-4 & 8 & $1.44 \mathrm{C}$ \\
IAC-6 & 4 & $1.18 \mathrm{C}$ \\
IAC-7 & 32 & $2.92 \mathrm{~B}$ \\
IAC-17 & 4 & $1.18 \mathrm{C}$ \\
FT-Cometa & 33 & $2.95 \mathrm{~B}$ \\
Cristalina & 36 & $3.08 \mathrm{~B}$ \\
Savana & 0 & $0.71 \mathrm{D}$ \\
Viçoja & 0 & $0.71 \mathrm{D}$ \\
Peking & 0 & $0.71 \mathrm{D}$ \\
Paraná & 0 & $0.71 \mathrm{D}$ \\
IAS-5 & 100 & $5.04 \mathrm{~A}$ \\
Bossier & 0 & $0.71 \mathrm{D}$ \\
IAC PL-1 & 6 & $1.40 \mathrm{C}$ \\
IAC-100 & 6 & $1.35 \mathrm{C}$ \\
CAC-1 & 8 & $1.56 \mathrm{C}$ \\
OC-4 & 7 & $1.49 \mathrm{C}$ \\
OC-14 & 0 & $0.71 \mathrm{D}$ \\
OC-3 & 27 & $2.74 \mathrm{~B}$ \\
JAB-11 & 5 & $1.27 \mathrm{C}$ \\
UFV-15 & 0 & $0.71 \mathrm{D}$ \\
UFV-14 & 1 & $0.84 \mathrm{D}$ \\
UFV-10 & 7 & $1.44 \mathrm{C}$ \\
UFV-1 & 0 & $0.71 \mathrm{D}$ \\
UFV-9 & 0 & $0.71 \mathrm{D}$ \\
UFV-5 & 0 & $0.71 \mathrm{D}$ \\
\hline
\end{tabular}

${ }^{1}$ Significant at the $1 \%$ level of probability. ${ }^{2}$ Means followed by the same letter did not differ by the Scott-Knott test at the 5\% level of probability.

embriões somáticos, cotilédones imaturos com 4-6 mm de comprimento foram cultivados em meio N10 para indução de calos embriogênicos, sendo empregadas, para cada cultivar, quatro placas de Petri contendo 20 cotilédones cada. Os tecidos embriogênicos foram transferidos 6 vezes, a cada 15 dias de intervalo, para novo meio N10, sendo contado o número de embriões somáticos por cultivar. Foi observada uma interação significativa entre cultivares de soja e linhagens de A. tumefaciens e a linhagem mais virulenta foi a A281. O tipo de opina aparentemente não teve efeito sobre a virulência das linhagens e os cultivares mais embriogênicos foram IAS-5, Cristalina, FTCometa, IAC-7 e OC-3.

\section{REFERENCES}

Bailey, M.A., Boerma, H.R. and Parrott, W.A. (1994). Inheritance of Agrobacterium tumefaciens-induced tumorigenesis of soybean. Crop Sci. 34: 514-519.

Bodanese-Zanettini, M.H., Ortolan, M.G.S. and Hu, C. (1993). Somatic embryoid induction from Brazilian soybean genotypes. Rev. Bras. Gen. 16: $129-134$

Byrne, M.C., McDonnell, R.E., Wright, M.S. and Carnes, M.G. (1987) Strain and cultivar specificity in the Agrobacterium-soybean interaction. Plant Cell Tissue Organ Cult. 8: 3-15.

Delzer, B.W., Somers, D.A. and Orf, J.H. (1990). Agrobacterium tumefaciens susceptibility and plant regeneration of 10 soybean genotypes in maturity groups 00 to II. Crop Sci. 30: 320-322.

Fehr, W.R. and Caviness, C.E. (1980). Stages of Soybean Development. Spec. Rep. \# 80. Iowa Cooperative Extensive Service, Special Report, 80. Iowa State Univ. Press, Ames, p. 32. 
Komatsuda, T. and Okyama, K. (1988). Genotypes of high competence for somatic embryogenesis and plant regeneration in soybean. Theor. Appl. Genet. 75: 695-700.

Lazzeri, P.A., Hildebrand, D.F. and Collins, G.B. (1985). A procedure for plant regeneration from immature cotyledon tissue of soybean. Plant Mol. Biol. 3: 160-167.

Mauro, A.O., Pfeiffer, T., Collins, G.B. and Vieira, R.D. (1994a). Study of the interaction between genotypes and positions of soybean explants on the medium for inducing somatic embryogenesis. Científica 22: 133-144.

Mauro, A.O., Pfeiffer, T., Collins, G.B. and Vieira, R.D. (1994b). Basic knowledge for studies involving inoculations with Agrobacterium tumefaciens in soybeans. Científica 22: 187-194.

Mauro, A.O., Pfeiffer, T.W. and Collins, G.B. (1995). Inheritance of soybean susceptibility to Agrobacterium tumefaciens and its relationship to transformation. Crop Sci. 35: 1152-1156.
Murashige, T. and Skoog, F. (1962). A revised medium for rapid growth and bioassays with tobacco tissue cultures. Physiol. Plant. 15: 473-477.

Owens, L.D. and Cress, D.E. (1985). Phenotypic variability of soybean response to Agrobacterium strains harbouring the Ti or Ri plasmids. Plant Physiol. 77: 87-94.

Petit, A., David, C., Dahl, G.A., Ellis, J.G., Guyon, P., Casse-Delbart, F. and Tempé, J. (1983). Further extension of the opine concept: plasmids in Agrobacterium rhizogenes cooperate for opine degradation. Mol. Gen. Genet. 190: 204-214.

Sambrook, J., Fritsch, E.F. and Maniats, T. (1989). Molecular Cloning: A Laboratory Manual. 2nd edn. Cold Spring Harbor Laboratory, Cold Spring Harbor, NY.

Snedecor, G.W. and Cochran, W.G. (1989). Statistical Methods. Iowa State Univ. Press, Ames, p. 509.

(Received March 9, 1999) 